\title{
Hacia una Arqueología de la Diáspora Africana en el Litoral rioplatense. Paraná (Entre Ríos, Argentina) como poblado fronterizo durante el siglo XVIII y comienzos del XIX
}

\section{Towards an Archeology of the African Diaspora on Río de la Plata Coast, Paraná (Entre Ríos, Argentine) as a border town during the 18 th and early 19th centuries}

\author{
Alejandro Richard \\ Centro de Arqueología Urbana, \\ Instituto de Arte Americano e Investigaciones Estéticas "Mario J. Buschiazzo", \\ Universidad de Buenos Aires, \\ Consejo Nacional de Investigaciones Científicas y Técnicas, \\ Museo de Cs. Naturales y Antropológicas "Prof. Antonio Serrano" (Argentina) \\ ale_rich37@hotmail.com
}

\begin{abstract}
Resumen
La Arqueología de la Diáspora Africana en la región rioplatense ha presentado desarrollos localizados en torno a diversas materialidades durante las últimas décadas. Sin embargo, la falta de diálogo entre nuestro campo disciplinar y otros campos de las ciencias sociales, y la réplica de categorías analíticas propias del discurso académico novecentista han dificultado la formulación de marcos conceptuales que respondan a los procesos socio-históricos locales. En el presente trabajo se analizan las representaciones dadas en torno a lo indígena, lo afro y lo mestizo en la producción historiográfica de la provincia de Entre Ríos, Argentina, en tanto generadora de sentido y discursos académicos. En base a resultados preliminares de investigaciones arqueológicas-históricas en la ciudad de Paraná, se reinterpreta la espacialidad ligada al mundo indígena, afrodescendiente y afromestizo de los siglos XVIII y XIX.
\end{abstract}

Palabras Clave

Arqueología; Diáspora Africana; Litoral Rioplatense; Paraná.

\begin{abstract}
The Archeology of the African Diaspora in the River Plate region has presented localized developments around various materialities during the last decades. However, the lack of dialogue between our disciplinary field and other fields of the social sciences, and the replication of analytical categories typical of the 20th century academic discourse have made it difficult to formulate conceptual frameworks that respond to local socio-historical processes. In the present work, we analyze the representations given around the indigenous, the Afro and the mestizo in the historiographic production of the province of
\end{abstract}

Esta obra está sujeta a la Licencia Reconocimiento-NoComercial-CompartirIgual 4.0 Internacional de Creative Commons. http://creativecommons.org/licenses/by-nc-sa/4.0/

(cc) BY-NC-SA 


\section{Alejandro Richard}

Entre Ríos, Argentina, as a generator of meaning and academic discourses. From preliminary results of archaeological-historical investigations in the city of Paraná, the spatiality linked to the indigenous, Afro-descendant and mestizo world of the 18th and 19th centuries is reinterpreted.

\section{Keywords}

Archeology; African Diaspora; Rio de la Plata Coast; Paraná.

\section{Introducción}

Los estudios en torno a la Diáspora Africana anclados en el pasado rioplatense han mostrado grandes avances durante las últimas décadas. Desde distintos campos disciplinares como la historiografía, la antropología histórica y la arqueología se ha indagado en aquel pasado generando interesantes discusiones alrededor de un creciente corpus de información tanto cuantitativa como cualitativa. Sin embargo, la arqueología es de estos campos científicos el que más dificultades ha encontrado para plantear y desarrollar investigaciones sostenidas en torno al proceso diaspórico africano en el cono sur.

Como ya se ha planteado, estas limitaciones se han dado en gran medida a partir del intento de inserción en nuestra región de categorías analíticas heredadas de otros contextos y a la falta de diálogo con otras disciplinas del campo de las ciencias sociales (Mantilla Oliveros, 2016; Stadler, 2015; Zorzi, 2015), donde la institución esclavista y los procesos étnico-raciales presentaron desarrollos diferentes. Se constituye entonces como tarea primordial aquella de indagar fuertemente sobre los procesos identitarios del pasado y problematizarlos (a ellos y a sus relaciones con el mundo material) evitando caer en simplificaciones y generalizaciones que han dado por tierra con los sucesivos intentos de investigar en torno a lo que en definitiva "no existió".

En este trabajo ${ }^{1}$ analizaremos cómo afectaron y afectan las construcciones identitarias e imaginarios impulsados por el Estado (y alimentadas desde la producción académica) en torno a nuestra percepción histórica y el modo en que pensamos desde las ciencias sociales la historia misma de la ciudad de Paraná, capital de la provincia de Entre Ríos (Figura 1). Allí se encuentra lo que se ha dado a llamar el "barrio del tambor", asociado por la historiografía local a la población "negra", tanto libre como esclavizada. El caso de estudio aporta herramientas para proponer algunos lineamientos hacia el desarrollo de una Arqueología de la Diáspora Africana en clave regional, donde toman centralidad los procesos mestizos entre los diversos actores coloniales y decimonónicos.

\footnotetext{
${ }^{1}$ El presente trabajo se ha realizado en el marco de una Beca Interna Doctoral de CONICET, y del proyecto PICT-2017-3306.
} 


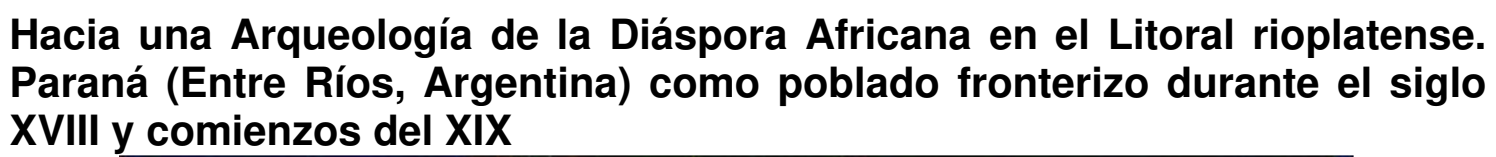

\section{XVIII y comienzos del XIX}

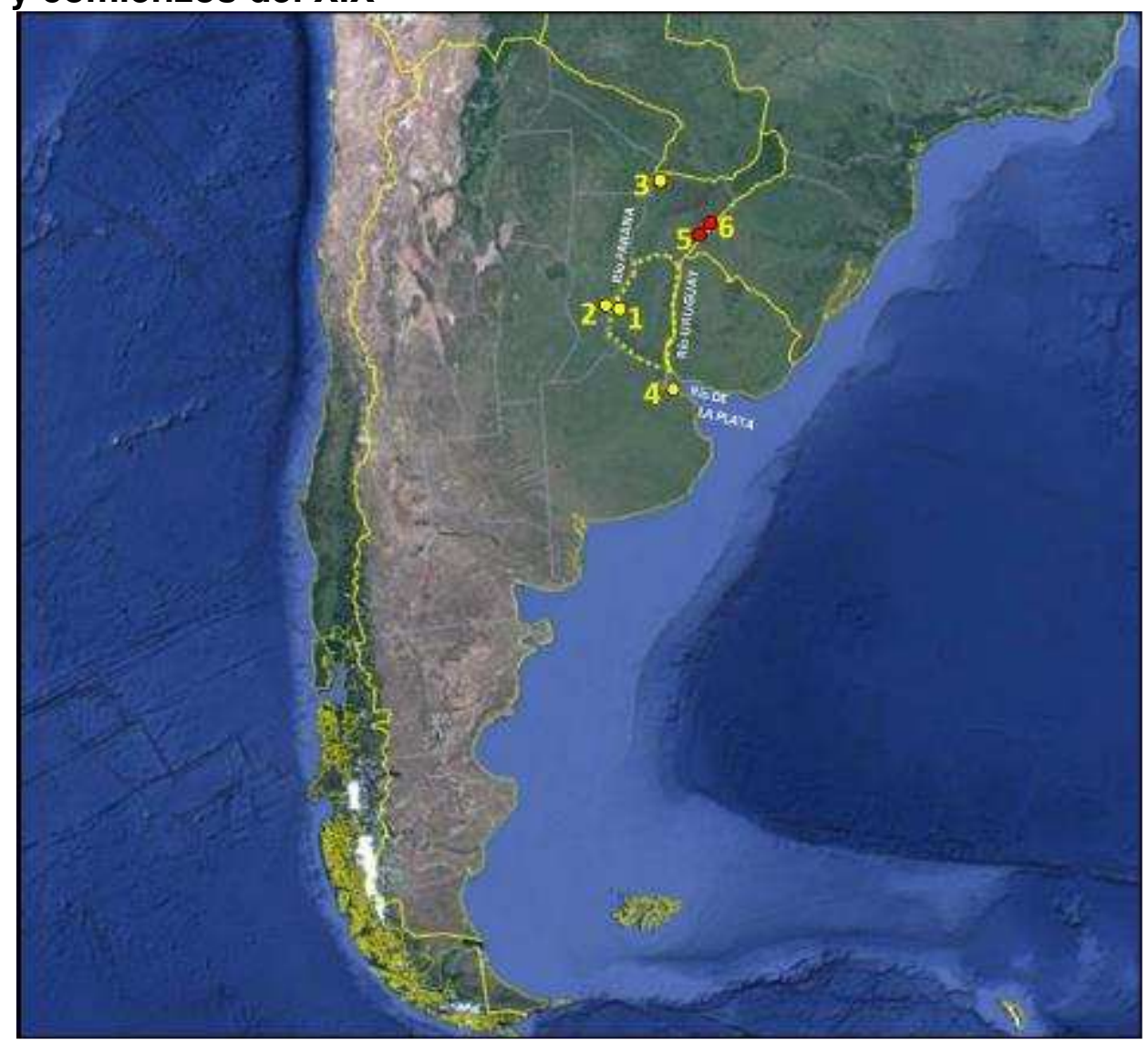

Figura 1. Sobre imagen satelital del cono sur sudamericano con su actual delimitación política, se destaca con línea de puntos la provincia de Entre Ríos (Argentina). Se identifican los ríos Paraná y Uruguay, y los pueblos y ciudades mencionados en el texto. En amarillo: Paraná (1); Santa Fe (2); Corrientes (3); Buenos Aires (4). En rojo, los pueblos jesuítico-guaraníes ubicados más al sur: Yapeyú (5), y La Cruz (6). Imagen de Google Earth 2021.

\section{La lente con la que nos miramos}

Podría decirse que hasta hace poco tiempo nos ha sido difícil pensar desde la historiografía y la arqueología nuestro pasado colonial afrodescendiente, indígena y afromestizo en el Río de la Plata. Más allá de las múltiples particularidades dadas en torno a los desarrollos disciplinares, consideramos que esta dificultad se debió a una construcción académica, discursiva y analítica, que pensó a los sujetos no-blancos como elementos en el mapa que irían a ser meros testigos del proceso colonial. Testigos inertes, carentes de agencia, que fueron perdiendo su "pureza cultural" y por ende desaparecieron.

Al momento de buscar los orígenes de aquella construcción, observamos que, si bien las herramientas de las que se valió el Estado-Nación argentino para constituirse como un elemento coherente y homogéneo fueron diversas y multifacéticas, tuvo en la estadística censal, la educación pública y los museos sus más importantes piezas 


\section{Alejandro Richard}

a la hora de apuntalar un relato identitario y un sentido de pertenencia a partir de la segunda mitad del siglo XIX (Otero, 1998).

Las realidades y procesos socio-históricos regionales que llevaron a la conformación de los distintos territorios provinciales dieron pie a que en cada una de aquellas provincias se desarrollara un discurso propio, aunque con matices, tendientes a "sintonizar" la historia y el "ser provinciano" con aquel respectivo a la Nación Argentina (Buchbinder, 2008; Leoni, 2019).

Cada provincia fue testigo a pequeña escala de la construcción de un "nosotros" occidentalizado, republicano, trabajador, civilizado y vivo, que se constituiría en la natural evolución de un pasado arcaico, colonial, incivilizado y ya muerto, desaparecido. Así lo hicieron a su turno las provincias de las diversas regiones atendiendo a sus procesos históricos y sus consecuentes particularidades socioétnicas.

En el caso de Entre Ríos, una provincia nacida en el mismo siglo XIX, otrora constituido su territorio como una región fronteriza marginal al control del gobierno colonial (figura 2), su profundidad histórica fue testigo de constantes procesos migratorios y de intercambio interétnico. Este territorio estuvo atravesado por períodos de fuerte inestabilidad política y conflictos bélicos hasta la década de 1870 . La inmigración europea que se acentuó a partir de aquel último cuarto de siglo dio pie al fortalecimiento discursivo de la idea de un "mestizaje" blanqueador seguido por el "crisol de razas" y la consecuente idea de la desaparición de los últimos relictos de existencia indígena, afrodescendiente y afromestiza.

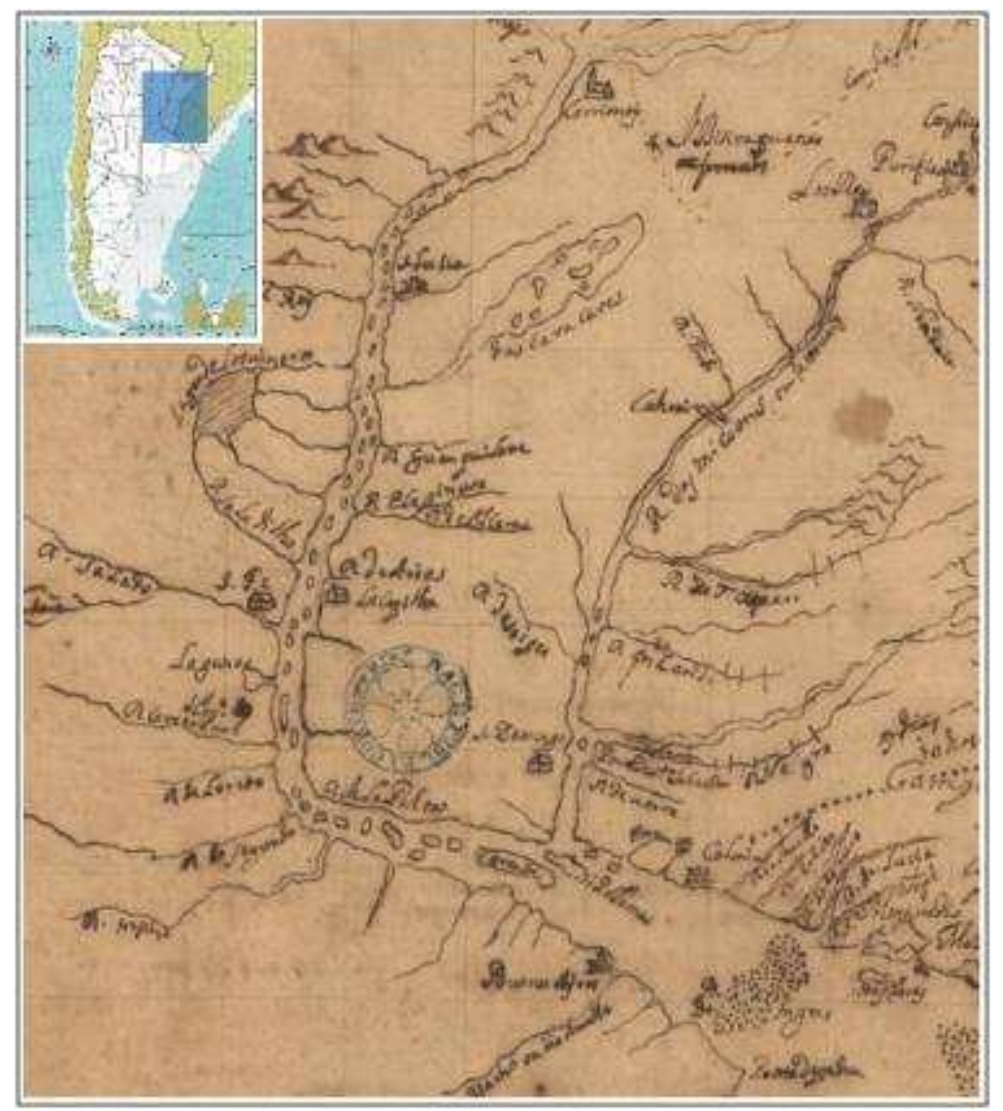




\section{Hacia una Arqueología de la Diáspora Africana en el Litoral rioplatense. Paraná (Entre Ríos, Argentina) como poblado fronterizo durante el siglo XVIII y comienzos del XIX}

Figura 2. Fragmento del "Mappa da parte meridional do Brazil. compreendendo desde o rio dos Ilhéus até o rio da Prata" (Biblioteca Nacional de Brasil), ca. 1700. En el actual territorio de Entre Ríos, a orillas del río Paraná, se consigna la presencia de "la Capilla" aproximadamente en el sector de la actual ciudad de Paraná, frente a Santa Fe.

Si actualmente existen en Entre Ríos personas que se autoidentifican como indígenas o afrodescendientes, ¿Por qué el sentido común regional niega o anula aquella existencia contemporánea? Podemos afirmar que en el "sentido común" entrerriano no se dimensiona el protagonismo desarrollado por indígenas, africanos y afrodescendientes en nuestra historia y constitución social, considerando su presencia como un capítulo de un manual escolar, lejano y sin continuidad con el presente.

Como señala Hall (2010), nuestro sentido común, episódico y multifacético, va dejando ver a modo de estratos los depósitos correspondientes a los sistemas filosóficos que operaron sobre él, por lo que apuntamos a la acción del sistema de educación estatal en torno a la construcción de un "nosotros" blanco-europeo y un "otro" indígena, africano, no-europeo.

En este relato construido desde el Estado y la academia, la historia entrerriana pareciera comenzar con una campaña poblada por "españoles" y algunos remanentes indígenas y negros, luego gauchos y criollos que irían a ser testigos del arribo de colonos europeos durante el siglo XIX, contexto en el que se diluyó la herencia colonial. Si quedaban guaraníes eran misioneros, si había algún charrúa era uruguayo. ¿Y los negros? En un pintoresco barrio de Paraná, a modo de postal decimonónica.

¿Cómo llegamos a percibirnos de esta manera?

En un proceso que se acentuó a partir de 1853, el Estado Nacional agudizó su retórica patriótica, estableció el servicio militar obligatorio y desarrolló el sistema educativo y sanitario, como así también un importante aparato estadístico. Este último actuó definiendo matrices mentales y discursivas tendientes a difundir una imagen de sociedad determinada que, al ser tomado como un corpus documental por los historiadores del siglo XX, tuvo un hondo influjo en el análisis histórico (Otero, 1998).

En este sentido, los censos nacionales del siglo XIX tuvieron al concepto de raza como fundamental, aunque en ningún momento hablaron de "un crisol de razas", sino de "mezcla de razas" (Otero, 1998). Esta idea, ligada al flamante darwinismo de la época, se relaciona con aquella del mejoramiento racial: ante la mezcla de razas, irán prevaleciendo los caracteres de mayor jerarquía, y los rasgos "negativos" se irán perdiendo en las futuras generaciones. Se construye así un "mestizaje desde arriba", que iría a articular como ideal homogeneizador de la identidad nacional (Mignolo, 2007). 


\section{Alejandro Richard}

Este mestizaje etnocida fue utilizado para suprimir memorias y silenciar genealogías originarias (y afrodescendientes), y tuvo un valor estratégico para las elites al cancelar las memorias de lo no-blanco por vías de la fuerza (Segato, 2010). Encontramos al "ser mestizo" propuesto, por ejemplo, en la temprana obra Montaraz de Martiniano Leguizamón ${ }^{2}$, de carácter literario, publicada en el año $1900^{3}$. Allí, sus personajes criollos de variado origen "no-blanco" son presentados como "una raza de centauros", más allá de que sus morenos rasgos se entrevén en el relato. Entre los personajes principales encontramos al "negro Patricio", cuya figura representa todo lo que un afrodescendiente debía ser para la elite provincial y nacional: "uno de los servidores del hogar de antaño", siempre alegre y dispuesto al sacrificio. Habiendo sido esclavo, recibió la libertad por parte de su amo en 1813 tras su heroica participación en un hecho de armas, pero de todos modos decidió permanecer junto a él.

El relato, situado en 1820, en torno a los últimos avatares de la gesta artiguista, plantea un "nosotros" de variada ascendencia, laborioso, civilizado, enfrentado al "recio trotar de barbarie" que significaba la invasión de los guaraníes de Artigas: allí se resalta la agilidad, astucia y movimientos felinos de los "indios" tan salvajes como ajenos a la entrerrianía. Ya veremos en páginas siguientes cuán presentes estaban hacia aquellos años las y los guaraníes en el conjunto de la sociedad entrerriana.

Al realizar un ligero repaso por la historiografía entrerriana de los primeros dos tercios del siglo pasado destacamos los trabajos de Benigno Teijeiro Martínez (1900 y 1913), Cesar Blas Pérez Colman (1930, 1937, 1943, 1946), Leoncio Gianello (1951) y Filiberto Reula (1969). Con matices, predomina la idea del mestizaje como "mejorador de la raza", tras la unión de indígenas y españoles, y de la escasa presencia de africanos y afrodescendientes. Estos últimos, además de estar destinados al trabajo doméstico, recibían un buen trato ${ }^{4}$. La labor evangelizadora de la Iglesia toma un rol central en Martínez, Pérez Colman y Reula.

Al comienzo del que fuera el primer intento por sistematizar la historia provincial, Martínez (1900) pone el eje en "la conquista", donde detalla campañas militares y enfrentamientos con los indígenas. La guerra de exterminio entre los "salvajes" charrúas y minuanes y los "valientes" españoles, está enfatizada por un momento posterior, donde "los indios infieles" fueron vencidos y desaparecen de la escena a mediados dl siglo XVIII. El territorio se habría plagado entonces de forajidos,

\footnotetext{
2 Martiniano Leguizamón (1858-1935), se constituyó en una de las grandes plumas entrerrianas. Habiendo cursado sus estudios secundarios en el Colegio Nacional de Concepción del Uruguay, luego recibido de abogado en la Universidad de Buenos Aires, fue un académico, historiador y coleccionista ligado al estudio del pasado entrerriano, sus costumbres y tradiciones. El museo Histórico de Entre Ríos, que lleva su nombre, se constituyó con piezas de su colección donadas por sus herederos.

${ }^{3}$ Aunque no incluimos en este estudio a Calandria, publicada algunos años antes, destacamos su construcción como una obra que plantea un criollo distinto del primer Martín Fierro o de aquellos ligados al "Moreirismo", es decir, mansos y trabajadores. Esta obra, recibida con loas por la opinión "culta" fue propuesta incluso para ser erigida en "símbolo nacional", optándose finalmente por el Martín Fierro, a partir de la intervención de Leopoldo Lugones en 1913 (Adamovsky 2019).

${ }^{4}$ La idea de una esclavitud local benigna, esbozada desde el nacimiento mismo de la historiografía nacional, fue indagada en profundidad por Rebagliati (2014).
} 
Hacia una Arqueología de la Diáspora Africana en el Litoral rioplatense. Paraná (Entre Ríos, Argentina) como poblado fronterizo durante el siglo XVIII y comienzos del XIX

ladrones y traficantes. No hay referencia a origen étnico alguno de esta gente, ni racialización. Simplemente, según Martínez, ante la “derrota del indígena”, el monte es habitado por agentes foráneos, bandidos y criminales.

En su vasta obra, Pérez Colman indaga con gran conocimiento y manejo de fuentes en las "corrientes de poblamiento" del territorio provincial, así como en la descripción de los grupos indígenas "entrerrianos", analizando además la materialidad arqueológica ligada a aquellos, y dedicando un apartado a "los últimos charrúas". En cuanto a las "corrientes pobladoras", el foco está puesto en la acción parroquial y la vasta labor evangelizadora de la Iglesia católica. En sintonía con esto, Reula (1969 t.1:94) afirmará que "en todo momento y en todo lugar de la conquista, está el sacerdote y en todo núcleo de población que se forma, está la capilla y en la cuna y en la tumba, está la cruz". En cuanto a la ascendencia de los pobladores de antaño, Pérez Colman no duda en afirmar que "nuestro criollo es de pura sangre española", y que jamás en la provincia sus habitantes "fundaron sus hogares con personas de raza negra o indígena" (Pérez Colman 1943:22).

En 1951, Leoncio Gianello publica su Historia de Entre Ríos (1520-1910), donde aborda detenidamente temas tocantes a "la raza" y el mestizaje. A diferencia de los autores anteriores, Gianello ve con buenos ojos al mestizaje, y en cuanto a los "indios y negros", sus comentarios redundan en el buen trato que se les daba, planteando mejores aptitudes para los trabajos rurales de los primeros sobre los segundos, lo cual -sumado a un alto costo y la pobreza del vecindario- explicaría la escasa presencia de esclavizados en Entre Ríos, confinados al servicio doméstico. Para finalizar, indica que la manumisión era muy frecuente: es más, era común que los esclavos rechazaban la libertad ofrecida (algo que ya nos suena familiar tras haber leído Montaraz).

Reula (1969) consigna que "la mestización de la raza con el "predominio" de los caracteres de la blanca, implicó necesariamente la de todos los aspectos de la vida colonial, también con la preponderancia de las modalidades del conquistador". Indica que "Las costumbres coloniales fueron pues, fundamentalmente españolas, pero "con sus virtudes atenuadas y sus defectos acrecidos", ya que las "costumbres bárbaras" de los aborígenes, no pudieron sino "gravitar en sentido peyorativo". (Reula, 1969 t1:101). Concluye afirmando que la indolencia y la holgazanería son lamentables características de la "raza mestiza" que se va formando en la colonia. Prosigue el autor planteando que una vez iniciada la inmigración de origen europeo a partir de mediados del siglo XIX, este componente "mestizo", criollo, se iría a diluir para pasar a ser simplemente parte del pasado, muerto y lejano. Durante el período 1854-1883, la afluencia cada vez mayor de inmigración europea habría favorecido "el emblanquecimiento progresivo de la raza". A la terminación del mismo, la población de la provincia puede considerarse "totalmente blanca". Aunque "si la raza ya es una, dentro de ella hay una neta diferenciación de nacionalidades". Nacionalidades blanco-europeas, claramente. 


\section{Alejandro Richard}

Planteamos que estas construcciones de sentido no son ingenuas, sino que se encuentran impregnadas de racismo y preconcepciones presentes en una escala vertical de jerarquías racializadas, propias del eurocentrismo en tanto forma de racionalidad específica de la modernidad (Quijano, 2014). El blanqueamiento llevado a cabo por la historiografía entrerriana fue planteado ya por Djenderedjian (2008) al tratar la presencia indígena en el sur provincial. Una relectura crítica de la producción académica precedente se constituye en tarea fundamental al momento de investigar desde las ciencias sociales en torno al mundo colonial y decimonónico, a fin de despojarnos de preconceptos colonialistas heredados. De este modo, el poder de innovación y la creatividad de los grupos indígenas y afrodescendientes como agentes de cambio social toman un rol importante al repensar la materialidad arqueológica y las espacialidades urbanas y rurales del período.

\section{Un territorio de frontera}

¿Qué clase de frontera conformaron las tierras de la actual provincia de Entre Ríos durante la colonia? ¿Y la región litoral? Pensamos en un amplio espacio fronterizo, caracterizado por una multiculturalidad en torno a prácticas mestizas, que recogieron elementos culturales de muy diverso origen (Boccara, 2001). Un espacio en constante cambio, donde la identidad y el sentido de pertenencia de los sujetos que lo habitaron estuvo ligado a cambios constantes tanto generacionales como trans-generacionales. Un espacio que a su vez no estaría únicamente compuesto por indígenas de una u otra filiación étnica diferenciados a rajatabla.

Al describir las relaciones conflictivas existentes entre los charrúas y los habitantes de los pueblos jesuítico-guaraníes de Yapeyú y La Cruz hacia la primera mitad del siglo XVIII, el Padre Pedro Lozano observa que cuando están en paz, concurren a los pueblos a intercambiar mercancías, y aunque los padres les predican sobre el negocio de su alma, difícilmente se convierten y

“(...) antes suelen ser de tropiezo a algunos flacos que arrastrados del deseo de libertad, se huyen a tierras de los charruas, que es la Ginebra de estas provincias, donde se refujian no solo indios, sino mestizos, negros y aun, lo que causa horror, algunos españoles que quieren vivir sin freno o tienen que temer de la rectitud de los jueces por sus enormes delitos, que alli continuan y agravan, viviendo peores que gentiles..." (Lozano 1873-1875: 410-411).

En 1738, tras algunos incidentes entre indígenas "rebeldes" y pobladores de la Bajada (actual Paraná), se generó cierta "paz", interrumpida cuando los indígenas atacaron el vecindario de Corrientes (ver Figura 1). Desde aquella ciudad se dispuso una expedición militar hacia el sur, "donde se guarecían”. Se dieron órdenes de pasar a todos los combatientes por las armas, y de separar "de dichos indios, a los españoles, negros, mulatos e indios cristianos" que con ellos vivían (Pérez Colman, 1937:130). 
Hacia una Arqueología de la Diáspora Africana en el Litoral rioplatense. Paraná (Entre Ríos, Argentina) como poblado fronterizo durante el siglo XVIII y comienzos del XIX

Comenzamos a dilucidar de algún modo "quiénes" fueron aquellos gauderios, montaraces y salteadores tan mentados por los autores analizados. ¿No había mujeres entre ellos? ¿Poseían alguna autoadscripción identitaria? Contrastando con la mirada androcéntrica y el modo estático de pensar a las socidedades del pasado colonial y republicano litoraleño, sostenemos que la dinámica propia de la región llevó al desarrollo de un mestizaje profundo a partir de la necesidad que tuvieron quienes la habitaron de inventar nuevos modos de subsistencia y soluciones en el cotidiano (Boccara, 2000). Este proceso alcanzó a los diversos sectores sociales, quienes experimentaron con el tiempo profundos procesos de etnogénesis. La "indeterminación" presente en la producción historiográfica del siglo pasado en torno a quiénes eran aquellas personas que habitaban la campaña, es el resultante lógico de una visión euro y androcéntrica que llegó a subestimar la capacidad de cambio propia de las sociedades indígenas y de quienes optaron por vivir por fuera del control colonial.

Ahora bien, podemos preguntarnos ¿Qué materialidad resultó de aquellas prácticas cotidianas? ¿Cómo articularon durante el período colonial los diversos grupos indígenas con aquellos de raíz europea y africana? ¿Qué es "lo afro" en un contexto como el nuestro?

Pensamos a las sociedades indígenas en constante cambio para momentos pre y post-hispánicos, derribando las concepciones de una "pureza" cultural prístina, como si a partir del contacto con elementos europeos aquellas culturas se hubieran contaminado (Boccara 2000, 2005) y dejaran de ser, por ejemplo, "guaraníes" o "chanás". En esta línea proponemos pensar lo afroamericano, y en concreto lo afromestizo, atendiendo a lo apuntado por Gwedolyn Hall (2005) al indicar que no existen patrones simples de "criollización", y por ende, los estudios sobre la diáspora africana deben ser concretos y contextualizacos.

\section{La Bajada del Paraná: sus orígenes coloniales y su composición socio urbana hacia el siglo XIX}

La ciudad de Santa Fe fue de los primeros asentamientos establecidos por España en los territorios del sur del continente. Juan de Garay, viajando desde Asunción para refundar Buenos Aires, que había fracasado en 1536, tenía como proyecto habilitar un acceso en el sur del Atlántico. A mitad de camino estableció en 1573 una ciudad sobre la margen occidental del río Paraná, a la altura de Cayastá. Santa Fe comenzó a articular el espacio colonial en ambas márgenes del ancho río. Tras su mudanza al actual emplazamiento (70km hacia el sur) a mediados del siglo XVII, algunos sitios aledaños comenzaron a tener un papel destacado; uno de ellos fue la llamada Bajada del Paraná, donde existía un puerto y canteras de piedra caliza en la barranca misma al río, en un sitio constituido en lugar de paso del río para retomar el camino a Corrientes. 


\section{Alejandro Richard}

Aunque durante las primeras décadas del 1700 era menester para las autoridades españolas establecer centros poblados en las inmediaciones de la ciudad santafesina para contener el avance indígena y poblar una región en puja con el imperio portugués, al cabildo santafesino no le era conveniente otorgar autonomía a un poblado que con el tiempo le quitaría sus tierras y recursos ganaderos más valiosos ubicados en la otra banda del Paraná. El pequeño rancherío de la Bajada se fue conformando en la ribera y luego tierra adentro, tomando cierto impulso hacia 1715 (Pérez Colman, 1930).

Cuando en 1727 el cabildo santafesino manda a levantar un fuerte para proteger el puerto de la Bajada, y otros dos fuertes tierra adentro para resguardo de las "familias" que habitaban aquellos parajes, se ordena que "por ningún modo deserten las familias y que las que hubieren desertado las apreendan y traigan", valiéndose de los cargos militares para "la faena de los indios, negros y mulatos" 5 .

Tras la insistencia del Gobernador y el arreglo del asunto con el Cabildo Eclesiástico, en 1730 se determinó aprovechar la existencia de una pequeña capilla ligada a uno de los fuertes recientemente levantados, para elevarla a Parroquia y fomentar desde allí el crecimiento del poblado (Pérez Colman, 1930, 1946; Sors, 1981). Esa fecha es la que se consideró para hablar del "nacimiento" formal de la villa, si bien la zona contaba hasta entonces con cerca de un siglo de poblamiento disperso y actividad en torno a los grupos indígenas locales ${ }^{6}$, la explotación de calcáreos y la instalación de personas tanto ligadas al gobierno colonial como marginales a este.

Durante el siglo XVIII el vecindario creció, y se construyó un nuevo templo que iría a reemplazar al anterior entre 1753 y 1756, y es a partir de aquellos años de donde provienen los documentos eclesiásticos que denotan la presencia no solo de españoles y criollos, sino también de indígenas de diversas etnias, africanos, afromestizos y una sociedad rica y dinámica propia de un área de frontera (Richard 2019a, 2021a). El profundo proceso mestizo se advierte al estudiar los registros eclesiásticos del siglo XVIII y comienzos del XIX, donde se observa una creciente generalización del uso de la categoría "pardo", y una fluida movilidad geográfica dentro del espacio mesopotámico de personas ligadas al mundo reduccional y de los pueblos jesuíticos de guaraníes (Richard, 2019a; Richard, 2021a).

En 1774 Félix de Azara describe al pueblo y Curato de moderna erección con 70 casas o ranchos (Azara 1873). Años más tarde, pasa por la Bajada es el Capitán de Fragata Juan Francisco de Aguirre, quien, anoticiado en 1784 sobre los orígenes del "pueblo o capilla de Nuestra Señora del Rosario de la Bajada", comenta que este se halla a dos millas del puerto habiéndose podido fundar en la barranca, habiendo sido "un bendito cura" el mayor opositor al traslado de la población hacia la barranca.

\footnotetext{
${ }^{5}$ Archivo General de la Provincia de Santa Fe (en adelante AGPSF), Actas Capitulares, 18-3-1727; IX f 383 a 384v. "El Alcalde 1o propone la construcción de un fuerte en el puerto de la Bajada, a raíz de las muertes que causan los payaguáes".

${ }^{6}$ Donde destacamos un primer pacto acordado entre el cacique Yasú y el gobernador Hernando Arias de Saavedra dado en la Bajada durante 1632 (Sallaberry 1926), y que el Cabildo santafesino otorgó en 1671 al Maestre de Campo Francisco Arias de Saavedra una encomienda de "indios tocagues" en el paraje llamado de "la Bajada" (Pérez Colman, 1930; Sors, 1981).
} 
Hacia una Arqueología de la Diáspora Africana en el Litoral rioplatense. Paraná (Entre Ríos, Argentina) como poblado fronterizo durante el siglo XVIII y comienzos del XIX

Según Aguirre, tras comenzar a poblarse a principios de aquel siglo, "Por el año 1740 ya tenían capilla, cuyos primeros ranchos alrededor fueron de unos pardos" (Aguirre 1951:386). Se desprende de este relato la temprana diferenciación entre el futuro "centro", ligado a la capilla de Nuestra señora del Rosario, y la Bajada propiamente dicha, ligada al río y distante de aquella.

El crecimiento del poblado continuó, y en 1809 se contabilizaron 150 viviendas ${ }^{7}$. Tras lograr la autonomía política, esta tendencia se acrecentó, y para 1820 se contabilizaron 781 viviendas y una población total de 4292 habitantes ${ }^{8}$, entre quienes contamos 243 personas esclavizadas.

En 1822 se firma el Estatuto Provisorio Constitucional, la primera carta magna provincial, que iría a reglamentar entre otras cosas la libertad de vientres sancionada por la Asamblea del año XIII.

Para 1824 disponemos de un censo más detallado ${ }^{9}$, elevado por el cura párroco. Allí se consigna una población de 3654 habitantes, de los cuales sólo 1708 son nacidos en Paraná: es decir, que la villa creció abruptamente por medio de la inmigración. Este crecimiento se dio durante aquellas décadas tras la llegada de vascos y catalanes (Pérez Colman 1946), pero también por el arribo -y en mayor número-, de guaraníes de las misiones y afromestizos santafesinos, continuando un proceso inmigratorio y de intercambio interétnico que se venía desarrollando entre las clases humildes del poblado desde el siglo XVIII.

En 1824 se consigna un 22,1\% de población afrodescendiente y un 11,5\% de "indios" sobre una población total de 3654 habitantes (Richard 2019a). Las personas apuntadas como "indios" consistían en indígenas de diversos grupos étnicos que habitaban el mundo colonial ya sea en la ciudad como en contextos rurales desde varias generaciones atrás, a quienes se les sumaban los guaraníes misioneros que migraban a los centros poblados desde mediados del siglo XVIII. Al ojo del empadronador, estas personas eran indígenas ya sea por su aspecto fenotípico (rasgos, pigmentación de la piel), su vestimenta, modo de hablar o de vivir en general. En ciudades como Concepción del Uruguay los guaraníes representaban el 10\% de la población para aquella década (Harman, 2010).

Por su parte, la población afromestiza censada estaba conformada de 626 "pardos" y 179 "negros": entre los primeros destacamos que menos de la mitad había nacido en Paraná, mientras que eran mayoría quienes habían nacido en Santa Fe, evidenciando un importante proceso migratorio de los sectores afromestizos santafesinos hacia la Bajada del Paraná durante los tres primeros lustros del siglo XIX. De los 179 "negros" censados, sólo el 22\% había nacido en Paraná, mientras que más de la mitad provenía del continente africano. De los lugares de origen consignados, se observa en orden de su relevancia a Angola, Congo, Mina y Benguela

\footnotetext{
7 Pérez Colman 1946, quien se basa en la petición elevada al Virrey por parte de los vecinos solicitando la autonomía.

${ }^{8}$ Censo de 1820, resguardado en el Archivo General de la Provincia de Corrientes

${ }^{9}$ Censo de 1824, resguardado en el Archivo General de la Provincia de Entre Ríos (En adelante AGPER). Fondo de Gobierno, Serie VII, Leg. 2.
} 


\section{Alejandro Richard}

(Richard 2019a). Entre la población africana y afrodescendiente el empadronador anota un total de 34 esclavizados, aplicando la categoría de "criados" a otras personas. Esto fue interpretado por Pérez Colman como un abrupto descenso en la cantidad de personas esclavizadas, debido a la aplicación del Estatuto, punto que refutamos en otro trabajo (Richard, 2021a) al comparar las curvas etarias de la población "esclava" de 1820, y aquella "esclava y criada" de 1824, tras lo que se pudo observar una llamativa coincidencia.

Al ojo del viajero Burmeister (1943), quien describió el poblado en 1857, la mayoría de sus casi 6000 habitantes eran "gentes pobres y de color". Se suma lo expresado por un pasajero del vapor Fanny ${ }^{10}$, quien recorrió la ciudad por aquel entonces, sorprendido por el crecimiento de la vegetación, la cual crecía "prestando su sombra a los juegos de los niños de color, chinitos y chinitas".

Durante los años en que la ciudad paranaense fue capital de la Confederación (18541861) se observó un mayor crecimiento edilicio y urbano, siendo este comparado con el crecimiento de las ciudades del Oeste estadounidense de entonces (Page 1859).

\section{El "Barrio del Tambor"}

Quien dedicó mayor cantidad de tinta en describir la existencia pasada de "africanos" y "negros" en la provincia fue nuestro laborioso Pérez Colman, quien se enfocó principalmente en la actual ciudad de Paraná. Fue el primero en describir "el origen" del barrio del tambor, poniendo sobre el papel lo que hasta ese momento era mera memoria oral, acompañada de un artículo de 1926 (Pérez Colman, 1926) y algunos recuerdos de la segunda mitad del siglo XIX editados entre 1906 y 1941 que mencionaban al barrio, a personajes o a las expresiones musicales afroparanaenses (Giménez, 1906; Velazco, 2018 [1929]; Segovia, 2017 [1941]). Dos de ellos recolectados, a su vez, en una nota periodística titulada "Los negros de Paraná" publicada en 1942 (Villanueva, 1942).

En la mencionada obra de 1946, al describir el poblado histórico en líneas generales, Pérez Colman menciona que en el sector norte en dirección al río, la población "estaba compuesta por morenos, en buena parte esclavos, que durante los sábados por la noche celebraban sus danzas africanas conservadas por tradición" (Pérez Colman 1946:60). Más adelante, en un capítulo dedicado a "la esclavitud en Entre Ríos" indica que

\footnotetext{
"Los negros libres y algunos de los sujetos a la esclavitud, habitaban con sus familias en los suburbios del pueblo, formando con sus ranchos primitivos, un barrio sui generis en los terrenos situados al norte de la ciudad, detrás de la manzana en que se edificó la iglesia San Miguel. En las quintas y laderas de las
}

\footnotetext{
${ }^{10}$ Relato publicado en El Nacional Argentino Nro. 69, del 3 de enero de 1854
} 
Hacia una Arqueología de la Diáspora Africana en el Litoral rioplatense. Paraná (Entre Ríos, Argentina) como poblado fronterizo durante el siglo XVIII y comienzos del XIX

barrancas, los negros habían levantado una especie de aldea, que trasuntaba el tipo característico de las poblaciones africanas" (Pérez Colman 1946: 229).

Aquí encontramos varios elementos para analizar. Aclaramos que la población no europea de la villa y ciudad de Paraná edificó viviendas de barro y "aparejo" en los márgenes del discreto poblado, al punto tal de que para 1809, el $83 \%$ de las viviendas de Paraná eran ranchos (Ceruti 2002), según consigna un documento elevado al virrey. Ahora bien, en su relato, los "ranchos primitivos" construidos por los negros libres y esclavos conformaron una aldea "sui generis" que "trasuntaba", es decir, imitaba "el tipo característico de las poblaciones africanas". Esta "aldea", además, se situaba "detrás" (mirando desde el centro, claramente, y no desde el río, que era desde donde se observaba e ingresaba al poblado) de la manzana donde se edificó la iglesia San Miguel.

Veamos, primero identificamos una constante relación esbozada entre lo "negro", o literalmente "africano", con lo primitivo. Cabe aclarar lo apuntado más arriba: en el censo de 1824 se apuntó a un 17\% de "pardos" y sólo a un 5\% de la población se les adjudicó la categoría de "negros", y de este pequeño porcentaje, sólo la mitad era nacida en el continente africano. Por lo que la descripción tan ligada al África parte más bien de una idealización y cosificación de lo "negro", separando al significante de su entorno histórico, cultural y político, e introduciéndolo en una categoría racial biológicamente constituida, lo que Stuart Hall (2010) llama "naturalizar una categoría histórica". Segundo, la referencia espacial ligada a la iglesia de San Miguel (que podría entenderse como una herramienta para ayudar al lector a ubicarse), dio pie a la creencia de que "los negros" se instalaron al norte, por encontrarse allí la capilla San Miguel. Así, no solo se alimenta el discurso que plantea el rol "civilizador" de la Iglesia, sino que se desvirtúa la temporalidad y profundidad histórica del proceso poblacional no-blanco paranaense. Desde la arqueología ponemos a discusión este punto.

¿Cuándo se formó aquel barrio? ¿Qué representa un "barrio" en un disperso poblado de cerca de 4000 habitantes? Observamos que la mención al "barrio del tambor" realizada por Giménez (1906) contrasta con la ausencia de aquella referencia geográfica o social dada por los viajeros que visitaron y describieron al poblado durante la época de la Confederación. Esto nos lleva a pensar en una apreciación local sobre un sector del poblado (de ocupación muy dispersa y precaria) identificado como un Barrio. El primero en mencionar estos terrenos en cuanto un "barrio", fue Giménez (1906), aunque en una clara asociación con el sector donde se encontraba la capilla y la iglesia de San Miguel en construcción, refirió al "barrio de San Miguel", sin connotaciones étnicas. De todos modos, una de sus particularidades habrían sido las ejecuciones musicales ligadas al mundo afrodescendiente. Giménez (1906) describe tres "parajes" donde "las diversiones" asociadas al candombe tenían lugar durante la época de la Confederación: estos tres puntos, si bien se disponen al 


\section{Alejandro Richard}

norte del centro histórico, se corresponden parcialmente con la referencia dada por Pérez Colman, desdibujando de algún modo aquella zonificación tan puntual.

Los viajeros extranjeros describen los difusos límites de la Bajada, la enorme distancia que separa el puerto del centro (donde se encuentra la Iglesia Matriz), al conjunto de la sociedad, a sus sectores humildes, pero no hacen referencia alguna al Barrio del tambor como un sector netamente diferenciado del poblado, incluso habiendo descrito como en los casos de Burmeister (en 1857) o Hutchinson (en 1868) la capilla de San Miguel y la iglesia en construcción (ver Figura 3).

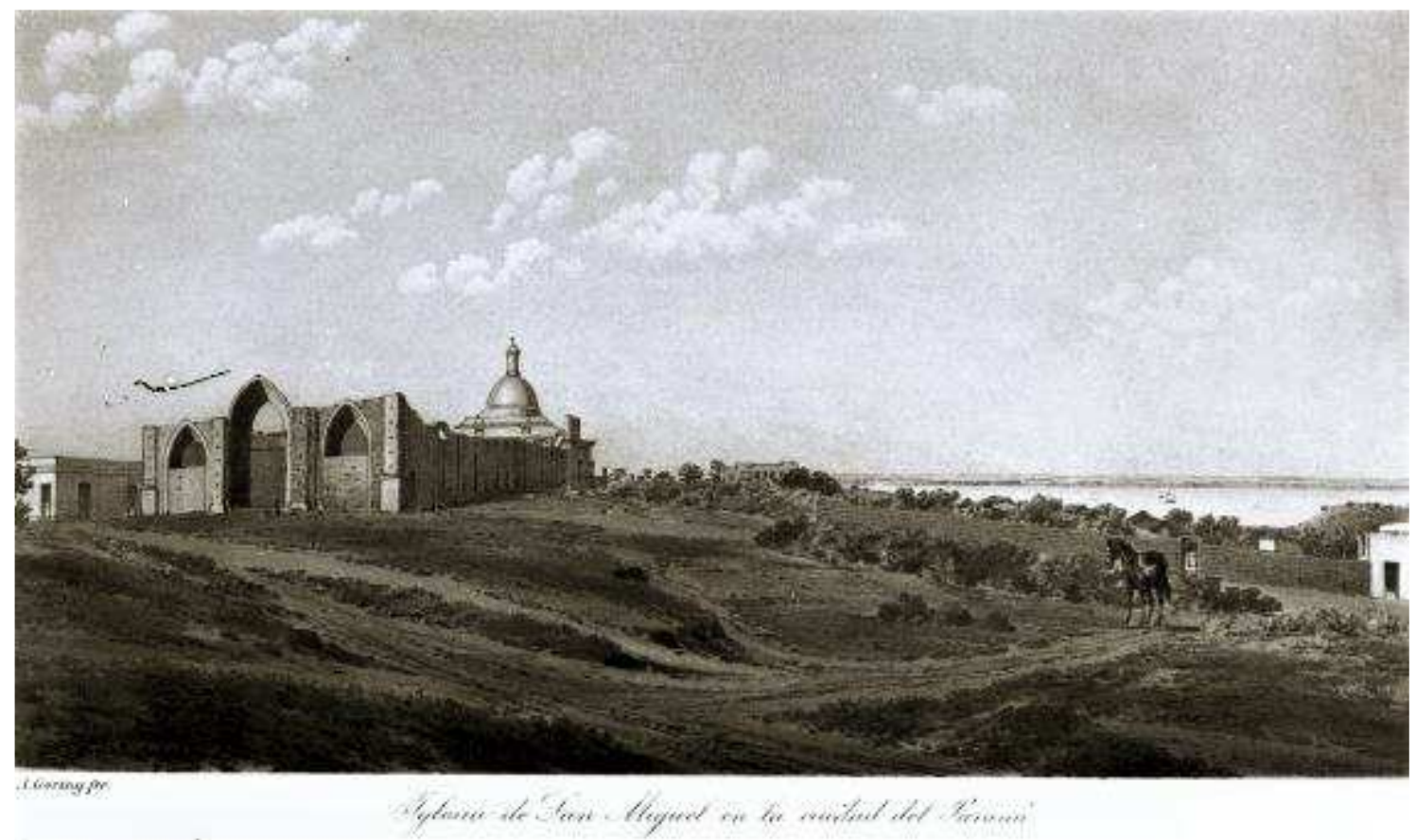

Figura 3: Grabado de Goering sobre imagen tomada por Burmeister en 1858 (fondo Biblioteca Nacional Mariano Moreno), desde actual plaza Alvear hacia el norte, se observa la Iglesia de San Miguel en construcción y la Capilla San Miguel Arcángel a su espalda. Destacamos la baja densidad urbana en los terrenos lindantes para momentos en que Paraná era Capital de la Confederación, la presencia de algunos ranchos con techos de paja a dos aguas ubicados en los terrenos en dirección al río, los desniveles naturales del terreno y la quinta de Du Graty al fondo, en el sector donde se emplazó el Colegio Nacional.

Pensamos entonces en los sectores ribereños, en la propia Bajada ligada al puerto, como también en aquella zona alta en inmediaciones de donde se construyó más tarde la capilla San Miguel, es decir: salvo el pequeño núcleo poblado que rodeaba la Iglesia Matriz, donde se destacaba una mayor densidad edilicia, la Paraná noblanca se habría dispuesto entre el "centro" y el río. El área del puerto viejo y la Bajada se constituye entonces en un sector de muy temprana ocupación sobre el que proyectamos indagar.

El seguimiento en torno a la propiedad de los terrenos donde actualmente se emplaza el Colegio $N^{\circ} 1$ "Domingo Faustino Sarmiento", ex Colegio Nacional, de los cuales poseemos datos desde la época de la Confederación (mediados del siglo XIX), grafican de algún modo qué clases sociales los habitaban 20 años después del 
Hacia una Arqueología de la Diáspora Africana en el Litoral rioplatense. Paraná (Entre Ríos, Argentina) como poblado fronterizo durante el siglo XVIII y comienzos del XIX

trazado de la Alameda de la Federación y la plaza Echagüe (actual Alvear), y los inicios de las obras de la nueva Iglesia San Miguel a espaldas de la capilla. Remarcamos que estos hechos, ocurridos hacia fines de la década de 1830, han sido interpretados como disparadores del proceso gentrificador que expulsaría a la población humilde de la zona (Pérez Colman 1946; Ceruti 2007; Suarez 2010; Richard 2019b).

Los terrenos en cuestión pasaron a manos del barón du Graty por medio de compra a tres propietarias distintas, y allí se instaló entre 1854 y 1858, la "quinta de du Graty", que se observa al fondo de la imagen de Burmeister (ver figura 3). En las escrituras de las compras realizadas por du Graty entre propietarias que venden y linderos (Martínez Segovia, 1989), se menciona a una serie de personas cuyas historias nos aportan información para imaginarnos aquel sector urbano hacia mediados del siglo XIX.

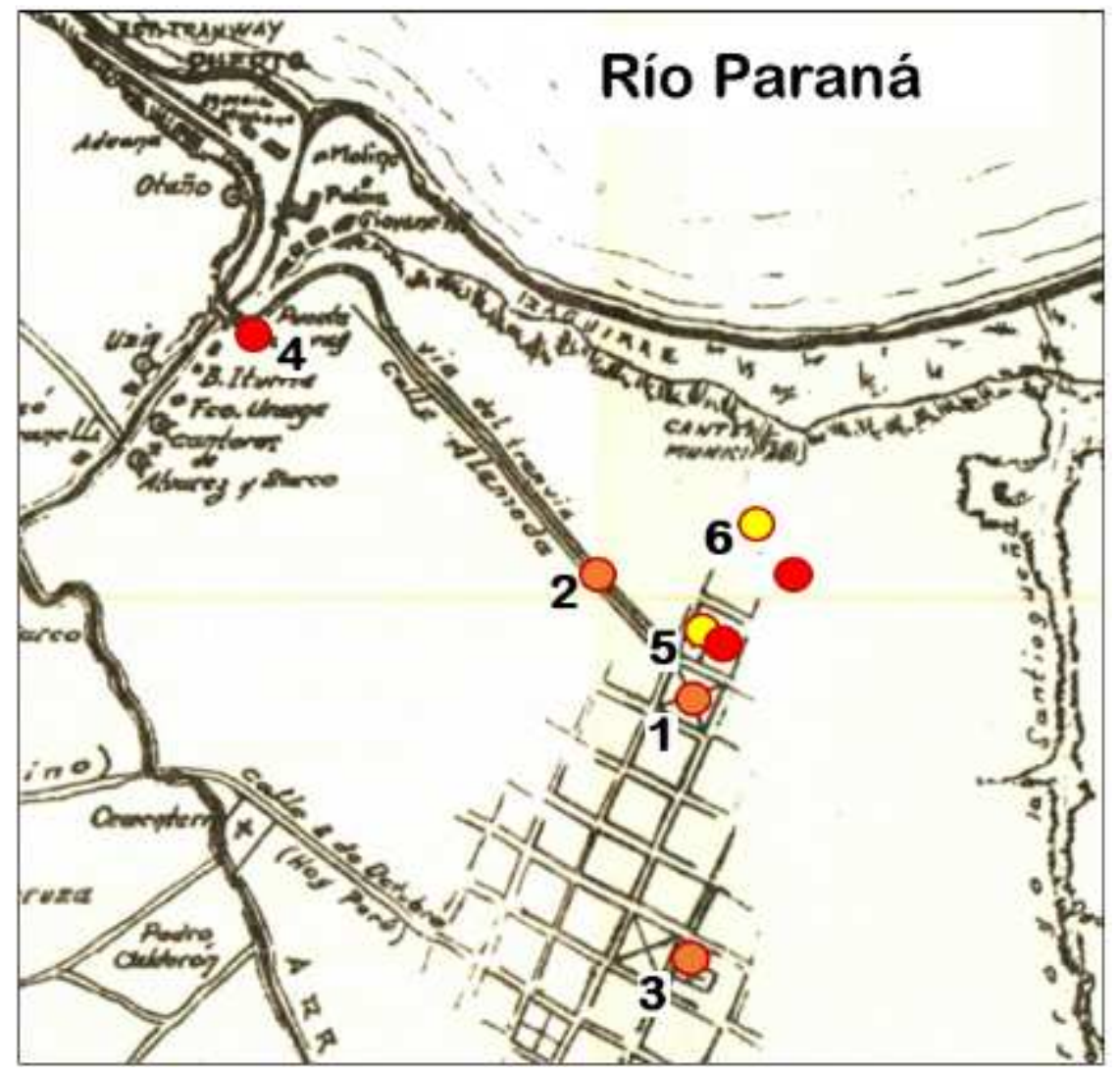

Figura 4. Sobre plano de la ciudad de Paraná que recrea el trazado hacia fines del siglo XIX, realizado por Sors (1981), se identifican lugares mencionados en el texto. En naranja lugares de referencia, en amarillo sitios excavados, en rojo espacios a intervenir arqueológicamente. 1- Plaza Alvear (a partir de 1836), antiguo "altos del molino"; 2- camino al puerto rectificado en 1836; 3- Actual Iglesia Matriz, "centro histórico"; 4- edificio en que funcionó la Capitanía General del Puerto viejo; -5 Capilla San Miguel Arcángel y “terreno norte de la capilla"; 6- Terrenos de la Quinta de du Graty (mediados del siglo XIX), luego Campo de deportes del Colegio Nacional. 


\section{Alejandro Richard}

Si indagamos en los terrenos situados al norte de la capilla San Miguel, observamos que, en 1854, el belga compró varios terrenos para edificar su quinta. Entre ellos, uno de 56,5x53,5 varas a Francisca Hernández"11, "india” santafesina que hacia 1824 vivía con su hijo José Anselmo Ramón Retamal, también santafesino, de profesión curtidor ${ }^{12}$.

Años más tarde, cuando du Graty vendió sus tierras, se incluyeron dos terrenos en forma de martillo. Uno de ellos, lindaba con el de Maria Olave y al norte con la "morena Casimira".

María Olave era hija de la africana Francisca Martínez, quien tenía 50 años en 1844 y falleció en $1865^{13}$. La "morena Casimira", resulta ser la también africana Casimira Puentes, censada en cercanías de Francisca Martínez en 1844, cuando tenía 40 años de edad. Hacia 1832, para cuando contrajo matrimonio con el africano Juan Bautista Bustamante, "moreno libre", Casimira era esclava de Doña Josefa González. Habría estado casada en primeras nupcias con Eleuterio García. Aquí surge un dato interesante: Eleuterio, consignado como García en el acta matrimonial, figura en otros documentos como Eleuterio Abitú, o Abizú, correntino, de evidente origen guaraní. Antes de aquel matrimonio Casimira tuvo al menos dos hijos naturales libertos, Demetria y Nemecio, cuyos padrinos fueron María Cámara y Bartolo Baster. Antes de contraer matrimonio con Bustamante, Casimira habría tenido estos hijos "naturales", pero habría estado casada en primeras nupcias con el correntino Eleuterio ${ }^{14}$.

\section{¿Qué comenzamos a observar desde la Arqueología?}

Al momento de desarrollar tareas de campo en el sector norte del actual centro paranaense (ver Figura 4), en dirección al río, no buscamos "encontrar al Barrio del tambor" bajo tierra, sino sumar elementos para comprender la dinámica de ocupación del espacio urbano, atendiendo a la composición socio-étnica de la Bajada entre el siglo XVIII y comienzos del XIX.

El campo de deportes del Colegio Nacional, emplazado en frente a donde se situó la casa de du Graty (demolida para construir el Colegio), fue rellenado y nivelado durante las obras desarrolladas a comienzos del siglo XX. Ya que la topografía original posee un desnivel (entre calle Buenos Aires y San Martín) de entre 3 y 3,5m, el evento de relleno fue intenso incluso en el sector oeste del campo de deportes,

\footnotetext{
${ }^{11}$ La reconstrucción de la tenencia de dichos terrenos se encuentra publicada por Ibañez (1989).

12 AGPER, Fondo de Gobierno, Serie VII, Leg. 2.

13 Archivo del Arzobispado de Paraná (en adelante AAP), Nuestra señora del Rosario, Paraná, Difuntos 1861-1866, f.235.

14Defunción de María Olave: AAP, Nuestra Señora del Rosario, Paraná, Difuntos 1861-1866, f.254. Matrimonio Casimira Puentes y Juan Bautista Bustamante: AAP, Nuestra Señora del Rosario, Paraná, Matrimonios, libro 3, f. 119. Bautismos hijos naturales de Casimira Puentes: AAP, Nuestra Señora del Rosario, Paraná, Bautismos, libro 4, fs.33 y 131. Matrimonio María Leonarda Avisú con Rosendo Aguiar: AAP, Nuestra Señora del Rosario, Paraná, libro f. 58v.
} 


\section{Hacia una Arqueología de la Diáspora Africana en el Litoral rioplatense. Paraná (Entre Ríos, Argentina) como poblado fronterizo durante el siglo XVIII y comienzos del XIX}

donde identificamos una potencia de 2,6m, debajo de la cual se halla el piso que habría estado expuesto hasta entonces. En excavaciones realizadas allí en 2018, no se registró materialidad arqueológica asociada al antiguo piso de ocupación (Figura 5).

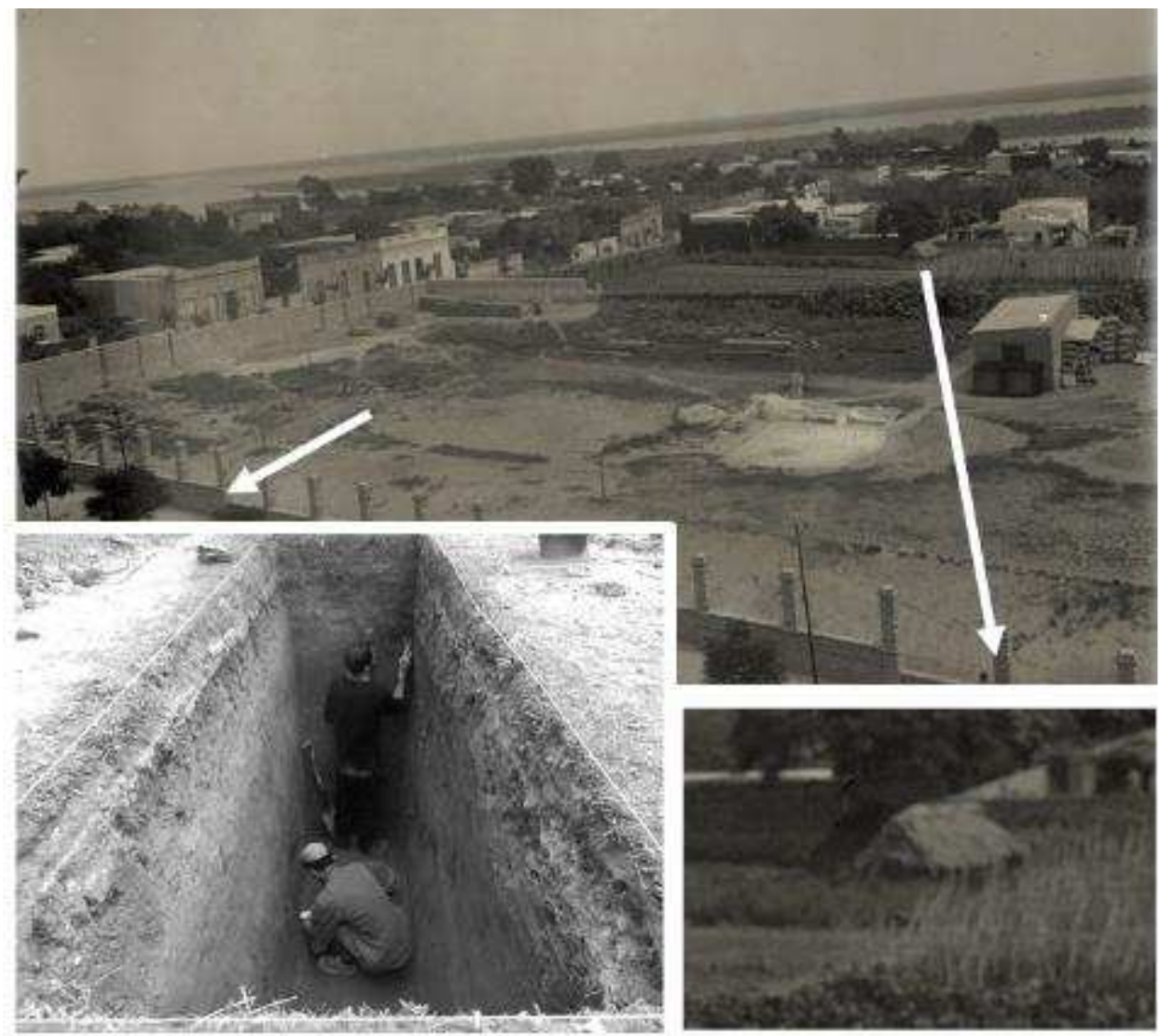

Figura 5. Sobre fotografía del Ministerio de Obras Públicas tomada desde la terraza del Colegio Nacional en 1925, indicamos la presencia hacia entonces de un rancho con techo de paja, probablemente remanente de los que allí se alzaban durante el siglo XIX, y el sector donde se excavó un sondeo arqueológico. Fototeca del Instituto de Arte Americano e Investigaciones Estéticas "Mario J. Buschiazzo"-UBA.

La construcción de la capilla San Miguel Arcángel fue iniciada, según la historiografía del siglo XX, durante el año 182215. En el marco de las tareas de restauración y puesta en valor del edificio histórico, se pudieron desarrollar trabajos de investigación arqueológica e histórica en torno al edificio (Schávelzon, 2020, 2021; Richard, 2021b). Schávelzon propone que el edificio actual es el resultado de diversas etapas constructivas ocurridas durante el siglo XIX, resultantes directos de la coyuntura política, económica y étnico-social paranaense a lo largo de aquel siglo.

15 Las diversas interpretaciones de un "Libro de Fábrica" (resguardado en el AGPER), donde se compaginaron fojas correspondientes a distintas obras arquitectónicas, dieron pie a posiciones encontradas en torno al inicio del proceso constructivo del edificio actualmente en pie a espaldas de la iglesia San Miguel. 


\section{Alejandro Richard}

Las intervenciones arqueológicas, efectuadas tanto dentro y fuera de la capilla, como también en el terreno lindante al norte de esta, aunque consistieron en pequeñas superficies excavadas, donde se recuperó una escasa materialidad arqueológica, aportaron interesantes elementos que enriquecen el modo en que pensamos aquel pasado decimonónico.

Como desarrollamos en otro trabajo (Richard, 2021b), la definición de dos momentos de ocupación del terreno, uno aparentemente contemporáneo a los inicios de la obra y otro anterior entre dos y cuatro décadas, se vio enriquecida por el hallazgo de fragmentos de adobes, y cerámicas relacionadas a la población hispano-indígena para el período colonial regional. Este tipo cerámico, monocromo rojo (Ceruti y Matassi, 1977; Schávelzon, 2018), presente en otros sitios a ambas márgenes del río Paraná (Parque General San Martín 1 en la provincia de Entre Ríos a $20 \mathrm{~km}$ de Paraná, y Santa Fe de la Vera Cruz y Santa Fe la vieja en la provincia homónima, ver Cocco, 2017; Richard y Ceruti, 2016) para momentos coloniales tempranos, abre nuestro abanico interpretativo a pensar hipotéticamente la presencia de población de ascendencia indígena en torno a estos terrenos en momentos previos a la construcción de la capilla. Si pensamos en la población africana y afromestiza local, como interrelacionada con aquella de ascendencia indígena, podemos atar cabos desde la arqueología, en torno a un tema que comienza a evidenciarse con fuerza desde los documentos históricos.

Con respecto al terreno ubicado al norte de la capilla San Miguel, donde sólo se realizaron dos pequeños sondeos, la materialidad arqueológica recuperada se encuentra asociada completamente a la vivienda que allí se edificó hacia 1906, en concordancia con lo observado por Ceruti (2007) en excavaciones anteriores.

Cuando páginas atrás describíamos los terrenos ubicados al norte del Colegio Nacional y a una de sus propietarias, "la morena Casimira", comentamos que años antes de su segundo matrimonio tuvo una hija y un hijo, en cuyos bautismos habían oficiado de padrinos Dolores Cámara y Bartolo Baster. Son ellos quienes vivían en el terreno contiguo al norte de la capilla San Miguel, según figura en una escritura de venta realizada en 1850 (Ceruti 2007). En 1848, su terreno con frente a la actual calle Buenos Aires no tenía vereda ni postes, habiendo alegado "indigencia" ante el funcionario que efectuó el relevamiento en el 4 to cuartel ${ }^{16}$. Dolores Cámara tenía 30 años hacia 1824, y era africana (mina) al igual que su marido Bartolo que en dicho censo se apellida Ramos, de origen "moro", y jabonero de ocupación. Hacia aquel año compartían vivienda con la negra María del Pilar Francisca, también "mora”, y su hija Petrona Chabez, uruguaya de 4 años. Podemos entrever redes de socialización, afinidad y movilidad geográfica entre personas africanas y afromestizas que habitaban en inmediaciones del terreno donde se edificó la capilla San Miguel.

La zona que separaba a los Altos del Molino (actual plaza Alvear) del Puerto viejo, estaba poblada por ranchos dispersos y algunas tierras con árboles frutales, según

${ }^{16}$ AGPER. Hacienda. Serie VII, Carp. 2, Leg. 6. Paraná, Nomina de vecinos que gozan alumbrado público, f.15. 
Hacia una Arqueología de la Diáspora Africana en el Litoral rioplatense. Paraná (Entre Ríos, Argentina) como poblado fronterizo durante el siglo XVIII y comienzos del XIX

se observa en los documentos de expropiación previos al trazado de la Alameda de la Federación en $1836^{17}$. En aquella oportunidad se indemnizó a 12 propietarios por la destrucción de 78 árboles frutales y la demolición de 11 cuartos y cocinas de estanteo y adobe. Si pensamos en una superficie aproximada de 3,3 hectáreas, vemos que el sector hacia el puerto se encontraba dispersamente poblado.

Planteamos continuar con los trabajos arqueológicos tanto en la zona norte del casco urbano paranaense, como en el área del Puerto viejo, por ser este uno de los sectores cuya ocupación remonta a los orígenes mismos de la Bajada, y se ha relevado una estructura, actualmente de vivienda, con elementos constructivos propios del período colonial tardío.

\section{Una Arqueología de la Diáspora Africana en clave regional como herramienta para comprender la historia social del Litoral}

Al momento de pensar cómo desarrollamos investigaciones desde la Arqueología Histórica en torno al proceso diaspórico africano en el litoral rioplatense, se plantean sobre la mesa diversos interrogantes en torno a las materialidades, espacialidades, y autopercepciones transgeneracionales propias de aquel mundo afrodescendiente y afromestizo. ¿Cómo atravesaron los procesos identitarios a las prácticas culinarias? ¿Qué formas de concebir la espiritualidad o el trabajo se desarrollaron entre estas personas en los distintos momentos y lugares? Sin dudas, las preguntas son casi infinitas, y las respuestas pueden buscarse en el estudio interdisciplinar de aquel pasado, es decir, poniendo en diálogo a diversas disciplinas y enfoques como la Arqueología, la Historiografía, la Antropología Histórica, la Etnohistoria y la Etnografía.

Más allá de la ya famosa discusión entre "africanistas" y “criollistas" planteada en el campo de la Arqueología desde que se comenzó a indagar en la materialidad arqueológica producida por actores africanos y afrodescendientes ${ }^{18}$, la cual excede los límites planteados para este trabajo, al pensar el contexto del litoral rioplatense se nos presenta la necesidad de replantearnos algunos enfoques.

Desde la Antropología y la Etnohistoria se ha avanzado en la interpretación de la dinámica identitaria americana de momentos coloniales y republicanos tempranos, considerando a las formaciones culturales como sistemas en constante cambio mediante la incorporación y adaptación de nuevos elementos, máxime en contextos fronterizos (Amselle, 1998; Gruzinski, 2000; Boccara, 2000, 2005). Si bien la

\footnotetext{
17 AGPER. Hacienda, Serie I, Caja 66, Leg. 4.

18 Esta discusión, que parte de las ideas en un principio contrapuestas de que la "cultura" de los africanos y africanas traídos a América y sus descendientes habrían perpetrado prácticas y elementos "africanos" o se habría desarrollado -a partir de la experiencia esclavista- un nuevo sistema cultural y simbólico, se ha desarrollado desde la década de 1940. Para el desarrollo de la Arqueología de la Diáspora Africana en Latinoamérica se pueden consultar Singleton y Sousa (2009), Mantilla Oliveros (2016), Sampeck y Ferreira (2020). Para Argentina ver Schávelzon y Zorzi 2014; Zorzi (2015) y Stadler (2015).
} 


\section{Alejandro Richard}

Arqueología misma se ha nutrido en cierto modo de aquellos debates y elaboraciones conceptuales para pensar contextos de contacto en nuestra región, desde la Arqueología de la Diáspora Africana no se ha avanzado en este sentido.

Pensamos que ante un marcado dinamismo cultural y movilidad social, el mestizaje y los procesos etnogenéticos fueron una constante entre diversos sujetos y grupos a lo largo del período estudiado. La intención de aplicar categorías heredadas de contextos disímiles (como las sociedades de plantación, o los quilombos y palenques) nos impide comprender la profundidad de los procesos locales en torno a lo afro. En este sentido, como apuntó Mantilla Oliveros (2016), es necesario no sólo repensar categorías -en nuestro caso en torno al proceso mestizo- sino entablar y nutrir un diálogo constante entre quienes nos encontramos trabajando desde la Arqueología de la Diáspora Africana en la región y la Arqueología Histórica en sí. Con esto no insinuamos dejar de lado los estudios sobre espacialidades y materialidades asociadas concretamente a una ascendencia africana o a la persistencia de elementos del mundo simbólico africano expresada en objetos de uso, como en los casos, estudiados por varios investigadores e investigadoras, de las pipas y objetos cerámicos de Santa Fe la Vieja, Arroyo Leyes, Alejandra, Buenos Aires o Tucumán ${ }^{19}$. Por el contrario, pretendemos abrir un nuevo frente en los estudios de la Diáspora Africana en la región Litoral, a partir de la consideración de la viva capacidad de cambio y resistencia propia del mundo afroamericano y afromestizo en los momentos históricos estudiados, particularmente en contextos fronterizos y marginales.

Proponemos pensar nuestro caso paranaense en torno a los conceptos esbozados en el presente trabajo, atendiendo a la futura ampliación de trabajos de campo en el entorno urbano. Planteamos como hipótesis que entre comienzos del siglo XVIII y primeras décadas del XIX se desarrolló un espacio periférico entre la bajada al río propiamente dicha, y el actual centro de la ciudad de Paraná, habitado principalmente por familias y personas de ascendencia mestiza no-blanca, donde destaca el componente afrodescendiente. Los elementos considerados llamativos, y luego romantizados, ligados a las prácticas musicales desarrolladas por algunas familias y personas agrupadas en diversos sectores de aquel espacio marginal, habrían dado lugar a la idealización y caracterización de aquel sector como "un barrio", donde los "negros" construyeron sus viviendas "imitando" las que habrían abandonado forzosamente en su continente ancestral. Al realizar una lectura multifocada del proceso colonial regional y local, atendiendo además a un análisis crítico de los constructos académicos y a nueva información proveniente tanto de la Historiografía como de la Arqueología Histórica, comenzamos a entrever algunos

\footnotetext{
19 Estos trabajos, entre los que destacamos los desarrollados por Carlos Ceruti y Daniel Schávelzon, fueron ya sintetizados por Schávelzon y Zorzi (2014), Zorzi (2015) y Mantilla Oliveros (2016). Podemos sumar aquí a los realizados desde aquel año hasta la fecha en torno a Tucumán, Paraná y a un objeto hallado en el Convento Santa Catalina de Buenos Aires (Chávez, 2017; Cirio, Schávelzon y Zorzi, 2019; Schávelzon, 2020)
} 
Hacia una Arqueología de la Diáspora Africana en el Litoral rioplatense. Paraná (Entre Ríos, Argentina) como poblado fronterizo durante el siglo XVIII y comienzos del XIX

matices presentes en aquel mundo "no-blanco" que fue hasta ahora pensado desde un nosotros "blanqueado".

\section{Agradecimientos}

A Milena Annecchiarico y Alicia Martin, cuyo seminario "Cultura, raza y nación en América Latina. Debates y aportes desde la antropología y los estudios culturales" me ayudó a pensar varias de las ideas aquí planteadas. A Magdalena Candioti por proponerme participar de este Dossier, y a quienes evaluaron anónimamente el artículo por sus contribuciones y comentarios.

\section{Bibliografía}

Aguirre, F. 1951. Diario. En la Revista de la Biblioteca Nacional, T.III, p. 386.

Amselle, J. (1998). Mestizo Logics. Anthropology of Identity in Africa and Elsewere. Stanford University Press.

Azara, F. (1873). Viajes inéditos desde Santa Fe hasta la Asunción y los pueblos de las Misiones. Buenos Aires, Revista del Río de la Plata.

Boccara, G. (2000). Antropología diacrónica. Dinámicas culturales, procesos históricos y poder político. En Guillaume Boccara y Sylvia Galindo (Eds.), Lógica mestiza en América. Temuco,Instituto de estudios indígenas, Universidad de la Frontera.

Boccara, G. 2001. Mundos nuevos en la frontera del Nuevo Mundo. En Nuevo Mundo, mundos nuevos, e-review (CNRS-Cerma), École des Hautes Études en Sciences Sociales.

Boccara, G. 2005. Génesis y estructura de los complejos fronterizos euro-indígenas. Repensando los márgenes americanos a partir (y más allá) de la obra de Nathan Wachtel. En Memoria Americana (13).

Buchbinder, P. (2008). La Nación desde las provincias: las historiografías provinciales argentinas entre dos Centenarios. Anuario del Centro de Estudios Históricos "Prof. Carlos S. A. Segreti" (8).

Burmeister, H. (1943). Viaje por los Estados del Plata 1857-1860. Buenos Aires, Unión Germánica de la Argentina.

Ceruti, C. (2002). Techos, paredes y pisos: elementos para el estudio de las técnicas constructivas en Santa Fe y Entre Ríos. En Actas del Primer Congreso Nacional de Arqueología Histórica. Mendoza. 


\section{Alejandro Richard}

Ceruti, C. (2007). Investigaciones histórico-arqueológicas en el entorno de la capilla vieja de San Miguel Arcángel, Paraná", en IV Congreso Nacional de Arqueología Argentina. Rosario, Universidad Nacional de Rosario.

Ceruti, C. y N. Matassi (1977). Evidencias de contacto hispano-indígena en la cerámica de Santa Fe la Vieja (Cayastá). Actas y Memorias del IV Congreso Nacional de Arqueología Argentina. San Rafael.

Cirio, N., Schávelzon, D. y F. Zorzi, (2019). ¿Guayaca o exvoto? Religiosidad popular afroargentina a través de un hallazgo en el Convento de Santa Catalina, Buenos Aires. Tefros (17).

Chávez, L. (2017). "De Lugares y Objetos". La diáspora africana en la ciudad de San Miguel de Tucumán, Norte de Argentina (Tesis de Maestría inédita). Instituto de Ciências Humanas, Universidade Federal de Pelotas, Pelotas.

Cocco, G. (2017). Del siglo XVII al siglo XX. Excavaciones arqueológicas en la obra de ampliación del edificio de los Tribunales, Santa Fe de la Vera Cruz. América (26).

Djenderedjian, J. (2008). Límites de casta y nuevos espacios de poder en la frontera. La sedición indígena de 1785 en Entre Ríos y un intento de interpretación. Anuario del CEIC (4).

Gianello, L. (1951). Historia de Entre Ríos, 1520-1910. Paraná: Ministerio de Cultura de la provincia de Entre Ríos.

Giménez J. (1906). Paraná, capital de la Confederación Argentina. Recuerdos históricos. Paraná: Salvador Florenza.

Groseián, A. F. (1971). La iglesia de San Miguel Arcángel y de Todos los Angeles. El Santo Patrono de Entre Ríos. Orígenes del Barrio de la Plaza. El Cura Álvarez. Paraná: S/D.

Gruzinski, S. (2000). El pensamiento mestizo. Barcelona: Editorial Paidós.

Hall, S. (2010). ¿Qué es lo negro en el mestizaje? En E. Restrepo, C. Walsh y V. Vich (Eds.); Sin garantías. Trayectorias y problemáticas en estudios culturales. Popayán: Envión Editores.

Hall, G. (2005). Slavery and african ethnicities in the Americas: Restoring the links. Chapell Hill: The University of North Carolina press.

Harman, A. (2010). Los Rostros Invisibles de Nuestra Historia: Indígenas y Africanos en Concepción del Uruguay. Entre Ríos, Editorial Universidad Autónoma de Entre Ríos- Honorable Cámara de Senadores. 
Hacia una Arqueología de la Diáspora Africana en el Litoral rioplatense. Paraná (Entre Ríos, Argentina) como poblado fronterizo durante el siglo XVIII y comienzos del XIX

Ibáñez, E. (1989). Sobre este Suelo. En Colegio Nacional "Domingo Faustino Sarmiento". Libro del centenario (1889-1989). Paraná.

Leoni, M. S. (2019). Las historias regionales y provinciales en Argentina: una aproximación desde la historia de la historiografía. Revista Escuela de Historia (18).

Lozano, P. (1873-1875). Historia de la Conquista del Paraguay, Río de la Plata y Tucumán. Buenos Aires: Casa Editora, Imprenta Popular.

Mantilla Oliveros, J. (2016). Arqueología y comunidades negras en América del Sur. Problemas y perspectivas. En VESTÍGIOS - Revista Latino-Americana de Arqueologia Histórica (10).

Martínez, B. (1900). Historia de la Provincia de Entre Ríos. Buenos Aires: Biedma e hijos.

Martínez, B. (1913). La fundación de Paraná. En El Monitor de la Educación Común (46).

Martínez Segovia, F. (1989). Colegio Nacional Domingo Faustino Sarmiento. Libro del centenario (1889-1989). Paraná.

Mignolo, W. (2007). La idea de América Latina. La herida colonial y la opción decolonial. Barcelona: Editorial Gedisa.

Otero, H. (1998). Estadística censal y construcción de la Nación. El caso argentino, 1869-1914. En Boletín del Instituto de Historia Argentina y Americana "Dr. Emilio Ravignani". Tercera serie (16 y 17).

Page, T. (1859). La Plata, the Argentine Confederation and Paraguay. New York: Harper \& Brothers Publishers.

Pérez Colman, C. (1930). La parroquia y ciudad de Paraná en su segundo centenario,1730-1930. Paraná, La Acción.

Pérez Colman, C. (1937). Historia de Entre Ríos. Época Colonial (1520-1810). Paraná: Imprenta de la Provincia.

Pérez Colman, C. (1943). Entre Ríos 1810-1853. Consideraciones sobre la función histórica, política y social del pueblo entrerriano. Paraná: Museo de Entre Ríos.

Pérez Colman, C. (1946). Paraná 1810-1860. Los primeros cincuenta años de la vida nacional. Rosario: Ed. del Autor.

Pérez Colman, E. (1926). ¡Cómo cambian los tiempos! En Alfeo Zanini (Comp.), Páginas de Oro de la ciudad de Paraná en su primer centenario 1826-1926. 


\section{Alejandro Richard}

Quijano, A. (2014). Colonialidad del poder, eurocentrismo y América Latina. En: Cuestiones y horizontes: de la dependencia histórico-estructural a la colonialidad/descolonialidad del poder. Buenos Aires: CLACSO.

Rebagliati, L. (2014). ¿Una esclavitud benigna? La historiografía sobre la naturaleza de la esclavitud rioplatense. Andes (25).

Reula, F. (1969). Historia de Entre Ríos: política, étnica, económica, social, cultural y moral. Santa Fe: Editorial Castelví.

Richard, A. (2019a). La población indígena y afrodescendiente de Paraná. Categorías socioétnicas entre 1755-1824. En Memoria Americana. Cuadernos de Etnohistoria (27-1).

Richard, A. (2019b). La población africana y afrodescendiente de Paraná durante los siglos XVIII y XIX. Aportes para su estudio desde la arqueología histórica. En Eva Lamborghini, Maria Lourdes Ghidoli y Juan Francisco Martínez Peria (Comp.) Estudios Afrolatinoamericanos 4. Actas de las Sextas Jornadas del GEALA. Buenos Aires: CCC.

Richard, A. (2021a). ¿Quiénes habitaban el oeste entrerriano a comienzos del siglo XIX? Visibilizando a la población afrodescendiente y afromestiza de Paraná, Alcaraz y la Matanza. En Magdalena Candioti y Orlando Gabriel Morales (Eds.) Esclavitud, Emancipación y ciudadanía en el Río de la Plata. Africanos y Afrodescendientes en Buenos Aires, el Litoral, Cuyo y Córdoba (1776-1860). Buenos Aires: SB Ediciones.

Richard, A. (2021b). Arqueología de la Diáspora Africana en Entre Ríos, sus desafíos y posibilidades. En Alejandro Richard y Daniel Schávelzon, El barrio del tambor. Arqueología Histórica en torno a espacios afro de Paraná. Buenos Aires: Ediciones del Centro de Arqueología Urbana.

Richard, A. y Ceruti, C. (2016). Investigaciones arqueológicas en el Arroyo Las Conchas: un aporte al panorama arqueológico del oeste entrerriano en los primeros tiempos de la colonia. Revista de Antropología del Museo de Entre Ríos (2-2).

Schávelzon, D. (2018), Catálogo de cerámicas históricas de Buenos Aires (S. XVI-XX), con notas sobre la región del Río de la Plata. Buenos Aires: Facultad de Arquitectura y Urbanismo, La Imprenta Digital SRL.

Schávelzon, D. (2020). Arquitectura religiosa afroamericana: una producción híbrida en la búsqueda de la identidad. La capilla San Miguel en Paraná, Argentina. En Arqueología de la Arquitectura, (17). https://doi.org/10.3989/arq.arqt.2020.014

Schávelzon, D. (2021). La capilla San Miguel en Paraná y la arquitectura religiosa afroamericana. En Alejandro Richard y Daniel Schávelzon, El barrio del tambor. 
Hacia una Arqueología de la Diáspora Africana en el Litoral rioplatense. Paraná (Entre Ríos, Argentina) como poblado fronterizo durante el siglo XVIII y comienzos del XIX

Arqueología Histórica en torno a espacios afro de Paraná. Buenos Aires: Ediciones del Centro de Arqueología Urbana.

Schávelzon D. y Zorzi, F. (2014). Afro-Argentine Archaeology: A Case of ShortSighted Academic Racism during the Early Twentieth Century. The Journal of Pan African Studies (7-7).

Sampeck K. y L. Ferreira (2020). Delineando la Arqueología Afro-Latinoamericana. VESTÍGIOS - Revista Latino-Americana de Arqueología Histórica (14).

Segato, R. (2010). Los cauces profundos de la raza latinoamericana: una relectura del mestizaje. En Crítica y Emancipación - Revista Latinoamericana de ciencias sociales (3).

Segovia, F. (2017). Del pasado entrerriano. Cuentos y anécdotas paranaenses. Paraná: Universidad Nacional de Entre Ríos.

Singleton, T. y M. Souza (2009). Archaeologies of African Diaspora: Brazil, Cuba, and United States. En T. Majewski y D. Gaimster (Eds.), International Handbook of Historical Archaeology. New York: Springer.

Sors, 0. (1981). Paraná, dos siglos y cuarto de su evolución urbana: 1730-1955. Paraná: Editorial Colmegna.

Stadler, N. (2015). Arqueología Afro ¿Es posible una arqueología de la diáspora africana en Argentina? En Juan Francisco Martínez Peria y María de Lourdes Ghidoli (Comps.). Estudios afrolatinoamericanos 2. Actas de las Cuartas Jornadas de Estudios Afrolatinoamericanos del GEALA. Buenos Aires: CCC.

Suarez, P. (2010). Los afro-argentinos de Santa Fe y Entre Ríos. El Corsito (38).

Velazco, M. (2018). Recuerdos de mi niñez en la ciudad de Paraná, 1877-1889. Paraná: Universidad Nacional de Entre Ríos.

Villanueva, A. (1942). Los Negros de Paraná. Diario El Litoral, 4 de octubre de 1942

Zorzi, F. (2015). La Arqueología de la diáspora africana en la Argentina. Desarrollo, problemáticas y perspectivas. Revista de Arqueología Histórica Argentina y Latinoamericana (9-2).

Recibido: 07/06/2021

Evaluado: $25 / 07 / 2021$

Versión Final: 30/07/2021 